\title{
Glaucoma-sleep apnea syndrome
}

INSERM

\section{Source}

INSERM. (1999). Orphanet: an online rare disease and orphan drug data base. Glaucomasleep apnea syndrome. ORPHA:2085

Glaucoma-sleep apnea syndrome is characterized by sleep apnoea associated with glaucoma. It has been described in five members of a family (the mother and four of her children). 